\title{
Biking Acculturation Incidence on the Cameroon Urban Activity Fluxes: A Traffic Congestion Panacea or Palliative in Bamenda?
}

\author{
Zephania N. Fogwe \\ Department of Geography and Planning, The University of Bamenda \\ PO Box 39, Bambili, Cameroon \\ E-mail:nfogwez@yahoo.co.uk
}

Received: November 21, 2019 Accepted: February 9, 2020 Published: February 22, 2020

doi:10.5296/ijgs.v4i1.16517

URL: https://doi.org/10.5296/ijgs.v4i1.16517

\begin{abstract}
City activity fluxes are reminiscent of stakeholder mobility in the urban sphere service and functions. Such mobility affects income and work assiduity though often creating accidents, material damage and pollution of varied forms of urban transportation that has lately witnessed the adaption to motorbikes as an alternatively favoured means of movement to that car. Salvaging economic depression and affordability has given biking an edge of success of recent which raises the recurrent question of its spatio-temporal and technical sustainability in in the freight sector. This paper evaluates the commercialisation of bike riding despite levied negativism perceptions in providing an alternative to the major urban problem of traffic congestion and its contribution to peter the pitfalls of the congestion. To assess the urban congestion intensity, traffic flow count was conducted during the rainy and dry season of spatio-temporal of vehicles (from the city centre to the suburbs). Findings agree to the fact that vehicular traffic congestion with increasing number of bikes was found to be higher along the N-E than the N-W road axis in direct conformity with sampled urban congestion triggers for Bamenda related to road infrastructural traits and vehicular numbers. Though motor bikes initially were a panacea, the sum effect of congestion reveals the urgent need for urban mass transport systems that should be complemented by a holistic urban transport governance involving the creation of deviation routes and enforcing traffic congestion rules.
\end{abstract}

Keywords: congestion, perception, motor bikes, roads, road users, vehicles 


\section{Macrothink}

\section{Introduction}

An increasing world urban population implies an increased concentration and crowdedness of services and functions at rates higher than sustainable service provision. Cameroon like other developing countries is handicapped by an urban facility planning and implementation that is far from aligning with good planning principles and practices. This exhibits a dearth of know-how and technology in human agglomerations of deficient traffic flow foresight. This lack of planning is accentuated by heralding economic, social and environmental challenges in which urban functional space grabbing and sprawl invite an uneasy connection between city service provision and consumption areas. The commonplace structure less patterns become the urban development paradigm with the chaos it imposes on its flow of goods and persons. The new cohabitation rush and rushing off hours by myriads of urban road users had as effect traffic cramming and road junction tailbacks is most observable along the $13 \mathrm{~km}$ road linking Bamenda III to Tubah and the $24 \mathrm{~km}$ road through Ntarikon in Bamenda II to Bafut (Figure 1a). These roads are located between longitude $10^{\circ} 8^{\prime} 29.70^{\prime \prime} \mathrm{E}$ and $10^{\circ} 15^{\prime \prime} 19.89^{\prime \prime} \mathrm{E}$ and latitude $5^{\circ} 57^{\prime} 40.60^{\prime \prime} \mathrm{N}$ and $6^{\circ} 0^{\prime} 19.62^{\prime \prime} \mathrm{N}$ (Figure 1b).

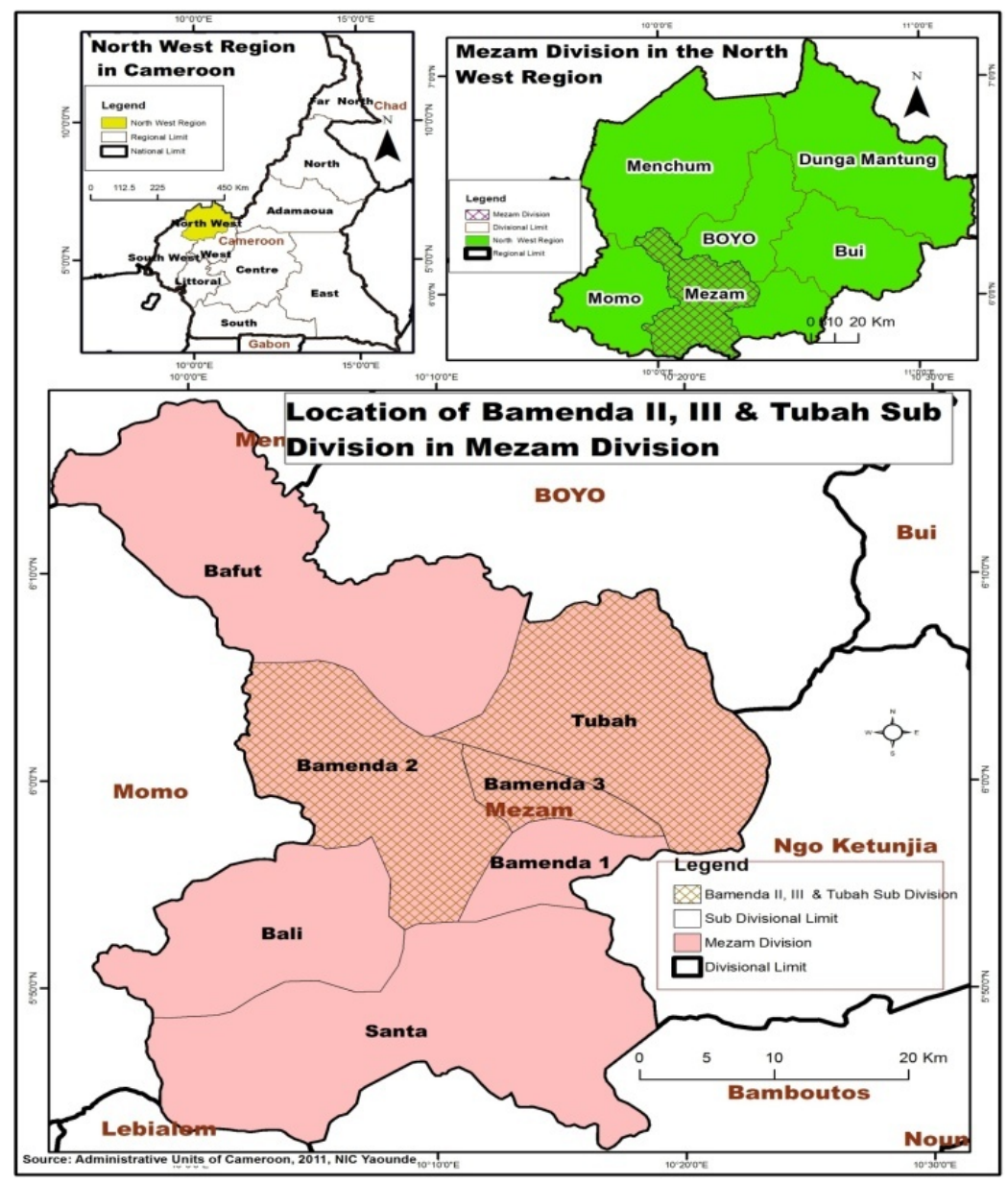

Figure 1a. Location of the study area in Mezam Division of Cameroon 


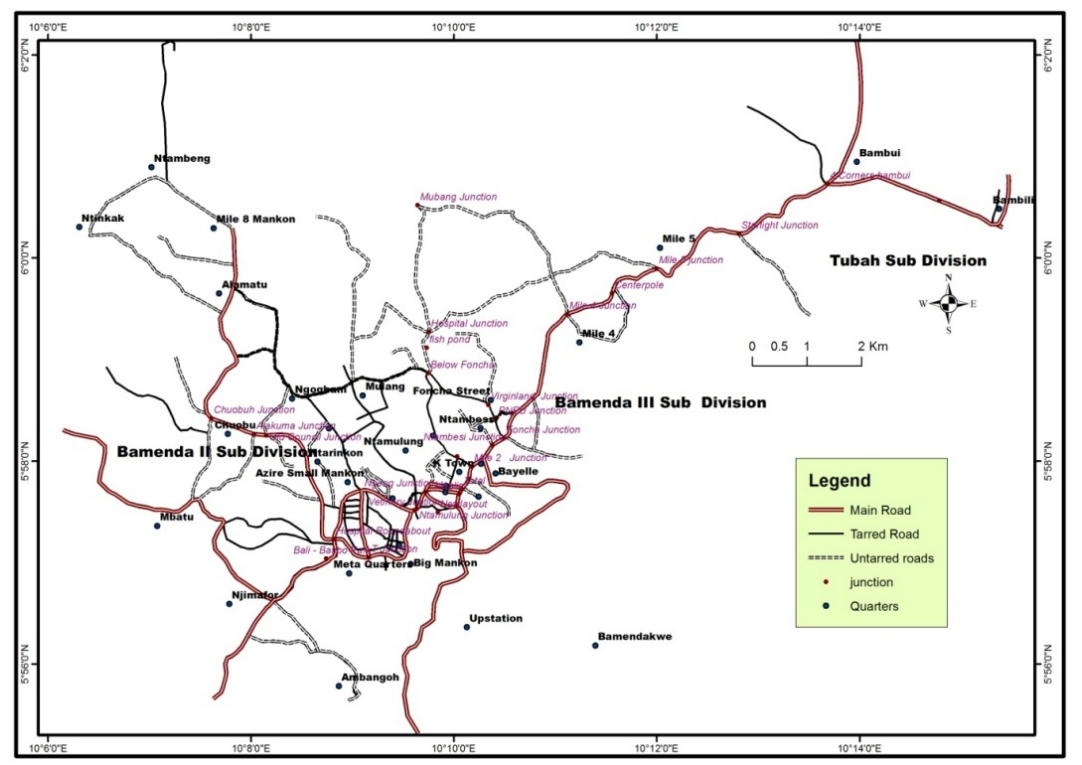

Figure 1b. Road axes studied in Bamenda city

\section{Conceptual Framework}

An assessment of a new mode of inter/intra urban transport like biking is scientifically beginning when anchored unto a conceptual model. This study chose to use the Spatial Interaction, Three Phase Traffic, and Traffic Flow theories to evaluate the relevance to the biking incidence on urban congestion.

Spatial interaction is a dynamic flow process (MacLachlan, 2015) involving the movement of people such as intra urban commuters or intercontinental migrants, goods like raw materials or flows of intangibles such as information. Though originating from early $20^{\text {th }}$ Century, Edward Ullman (1980) shaped spatial interaction to be a product of complementality, transferability and intervening opportunities indicators that demonstrate the flow of goods and people from Nkwen and Bambili, Ntarikon and Bafut. Bambili university town, Bambui and Nkwen are midway hubs serving as complementary places for the NE road axis whose demand and supply range of goods and services stretches beyond Ndop and Babanki Tungo. Meanwhile along the NW road axis, it is Ntarikon and Bafut that are complementary hubs demand and supply range of goods for Lower Menchum and Wum. Road users could prefer to shop in Bambili and Bambui as a supply point offering all that Nkwen does along the NE axis or shop at Mile 8 Mankon rather than Ntarikon and Bafut along the NE axis.

The Three Phase Traffic Theory of Boris Kerner, (2012) explains the congestion by the phase transition in the traffic system. Three phases in traffic include free flow and two congestion phases which are synchronized flow and wide moving jam. It considers urban traffic parameters like safety gap between vehicles, average vehicle length and time delay for acceleration but the main parameters for the empirical evaluation of the three phase theory are velocity, density and flow rate of vehicles. The variance in congestion is much larger than free flow as it is common along the NE road axis where from Nkwen to Bambili, vehicles 
accelerates at a relatively high speed because traffic is low especially as one moves from The University in Bamenda, National Polytechnic in Bamenda. The speed of vehicles usually drops towards Mile 4 and much more towards AMOUR MEZAM EXPRESS and MOBIL Nkwen. This is the hot spot of traffic congestion because the density of vehicles is high. In synchronized flow, the speed of vehicles drops significantly, but there is a noticeable change in the flow rate observed. Along the Nkwen - Bambili road, this occurs at Mile 4 Junction where although the speed of the vehicle drops, traffic density and flow is moderate since there are sand trucks which occupy the road forcing the cars slow up. Wide moving jam propagates backward with mean velocity especially at MOBIL Nkwen, traffic density is highest and also highest at Ntarikon in the NW road axis. This is due to the narrow nature of the road as well as the high concentration of commercial activities so that cars and motorbikes accelerate at variable speed.

The Traffic Flow Theory of Immers and Logghe (2002) established relationship between traffic flux (vehicles/hour) and traffic density (vehicle/km) in order to predict the capability of a road system or its behaviour when applying inflow regulation or speed limits. This model establishes the connection between traffic density and vehicle velocity in that the greater the number of vehicles on the road, the slower their velocity. This is observable along the NE road axis especially around AMOUR MEZAM EXPRESS and MOBIL Nkwen on the NE axis as well as around Hospital Roundabout and Ntarikon in the NW road axis where the highest number of vehicles drive past thereby affecting the speed at which they move. To mitigate congestion and stabilise traffic flow, the number of vehicle entering the control zone has to be smaller or equal to the number of vehicles leaving the zone at a given time. This could be a way to tackle congestion at Mile Two (MOBIL) and Ntarikon where the number of cars circulating is greater than those leaving it to Bambili, Ndop, Bafut, Wum and other localities in Bamenda.

The speed reaches zero when the density equals the jam density. This is typical along the NE road axis especially when vehicles from Bambili and Bambui from Tubah subdivision are about to enter the core of Bamenda III around Mile III and moving towards Mobile Nkwen in Mile Two and also along the NW road axis where vehicles leaving Mankon and Bafut enter Bamenda II around Ntarikon and then towards Hospital Roundabout. The speed of cars reaching these areas in Nkwen decrease considerably partly because of the narrow nature of the road and many potholes. This area is full of most commercial activities and a large market.

The most directly relevant concept to this study thus is the Traffic Flow Theory which establishes a relationship between traffic flux and traffic density. The study posits on what this model predicts to causing traffic congestion along the northern road axis of Bamenda. The study concords with Rosen (2013) who observed that traffic congestion is issuant of multiple causes being too many cars for the roadway compensating for inadequate mass transit options or other reasons while Rumani (2014) confirmed that the major cause of traffic congestion is the substantial increase in the number of vehicles just as it has been the case towards the NE axis since 2011 when The University of Bamenda went operational. Notwithstanding Shbaklo et al. (1990) observed that days of the week are a significant factor 
in traffic flow measurement in Athens in confirmation of Rakha and Van Aerde (1992) that traffic flow on Tuesdays, Wednesdays and Thursdays were equal, but differed for Monday, Fridays and weekends in Athens. There are equally seasonal factors as noted by Memmott and Young (2008) and Lam and Toan (2006).

\section{Methodology}

The study area, Bamenda significantly replicates the advent and practice of motor biking Cameroonian towns and equally permits a survey that can observe of the causes of urban traffic congestion and as well as its impact. Data for this purpose were collected from primary and secondary sources for a qualitative and quantitative research. Primary data was essentially obtained through direct observation, questionnaire and interviews of key informants such as the Regional Delegation of Transport, the Regional Directorate of Roads as well as the Delegation of Public Works for first hand opinion on the causes of traffic congestion as well as mitigating measures especially from the Department of Traffic at the Bamenda City Council with regards to traffic management. Some 100 questionnaires were administered to regular (daily) city road users distributed equally along the north-east and north-west main road axis to permit a spatial assessment of traffic congestion distribution and impacts using a systematic and stratified sampling technique. As such a 5\% systematic sampling was done where every $5^{\text {th }}$ driver ply each axis. Student living within the city centre and so do the daily pendular migration to and from the peripheries were stratified according to chosen departments across the schools and faculties of The University of Bamenda in order to avoid double counting before randomly selecting while maintaining gender equity. This was carried out during school going period at intervals between June 2018 and July 2019. In August 2018, a daily traffic count method was done to determine the situation at the start of the rainy season and this was repeated in December 2018 for the dry season scenario. This permitted an identification of congestion hot spots at specific hours of the day and reasons for such congestion. Secondary data were obtained from text books, journals, articles and magazines from the internet. Maps and statistical data were collected from the Regional Delegation of Transport, Regional Delegation of Public Works as well as the Bamenda City Council. These were analysed by descriptive and inferential techniques were used to generate frequency tables, bar charts and pictures.

\section{Presentation of Results and Discussion}

\subsection{Motor Bike Riding in Bamenda: Commercial Motive Genesis}

Motor biking as a commercial venture did not start with the creation of Bamenda town but is rather a recent phenomenon. After the economic crises of the 1980s, the political crises of ghost towns and civil disobedience of the 1990s, what was left city roads dilapidated from the combined effects of weather and managerial neglect. Urban mass transport systems in the primate cities of Yaounde and Douala halted and by so doing unofficially making way for clandestine mass transport cars (clandos) of sizes, ages and states of roadworthiness to venture. Informality and disorder gripped urban grounds as motor bikes joined the chorus tuned by one of President's visit to China authorising the importation of their motor bikes to Cameroon. This became the springboard of a new revolution in the urban transport sector in 


\section{Macrothink}

Bamenda as hitherto bicycles and motor cycles with invisible incidence on commercial transportation, were to surrender to the large number and brands, on the few narrow streets, for Made in China motor cycles, imported new and at a cost price that was at most one third cheaper of the existing ones.

Affordability combined with the excitement of riding such new cheap bikes decorated with more fanciful gargets to attract an eager youth force that unemployment was weighing down. This novel veritable biking culture and revolution gripped the transportation of people and goods within the Bamenda urbanscape mobility geography as a complementary and competitive transport options between hawkers, cars, buses and pedestrians on narrow roads. Within the city, there the appeared to be only fewer areas of fluid mobility (Cow Street, Ghana Street, Up Station and Savannah Street) as compared to the more numerous areas of stuffed circulation (Food Market Street, Ngeng Junction, Hospital Roundabout, Veterinary Junction, MOBIL Nkwen to AMOUR MEZAM EXPRESS, and Mile 4 Nkwen, Commercial Avenue and Ntarikon (Figure 2).

Quick instant incomes drained more and more youths into the venture so that urban areas soon started witnessing overcrowding especially around pot holes where vehicular flow speed had to slow down. Such traffic bottlenecks soon entangled the city access ways such that the Bamenda City Council had to embark on some road improvement schemes like paving of the Ngeng Junction, reworking of the Hospital Roundabout, constructing deviation roads as from Ngeng Junction to SONAC Street, Old Town Council to below Foncha, and Cow Street through K-Town to Ndamukong Street, inside Old Town, Foncha Street to Farmer's House, Ngeng Junction through Ntamulung to SONAC Street, Commercial Avenue through Savannah Street to Old Town and AMOUR MEZAM EXPRESS to Station. These works in Bamenda II and III also benefitted from the Trans-African Highways that leads to Batibo, Mamfe and then to the Federal Republic of Nigeria from Azire New Church Junction in Bamenda II.

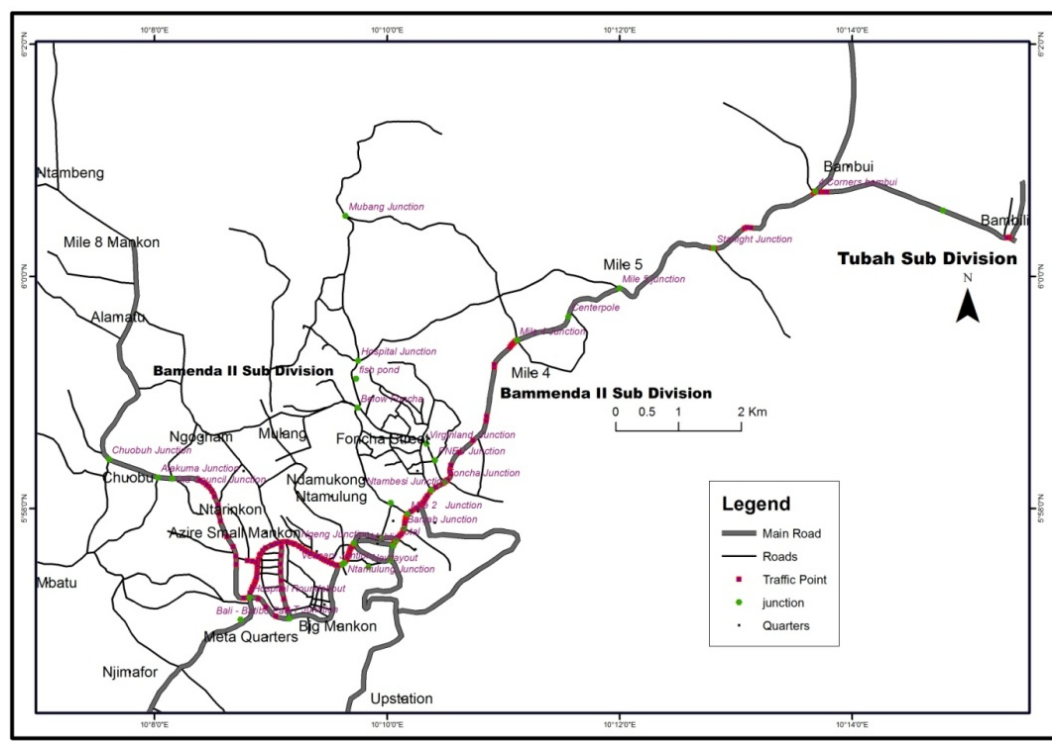

Figure 2. Areas of frequent traffic congestion in Bamenda

Source: May 2018. 


\section{Macrothink}

For most of the other areas of the town, traffic flow remains a daily huddle especially the in activity-population concentrated sections along whose roads lead to other towns and areas of the Region like Bafut and Wum in Menchum Division in the North West (NW), then Bambui, Bambili, and Babanki, Mbingo, Njinikom, Fundong in Boyo Division as well as Sabga, Ndop, Jakiri, Kumbo, Ndu, Nkambe, Ako, Abongshire and Mesaje to the North East (NE). This implies that traffic flow towards these areas suffers from car traffic jam pressure to transport goods and persons. A partial solution came from the advent of bikes which is what this study sought to assess whether it can succeed to truly resolve the urban traffic flow challenge in Bamenda.

\subsection{Biking Panacea to Triggers of Traffic Congestion in Bamenda}

Traffic congestion is commonplace problem rocking inner and outer city areas of Cameroon and increases where there is an inverse relationship between road users to road size, density and number of nodes. It has been observed that congestion has become a trouncing along the NE and NW road axes of the Bamenda metropolis which have emerged as bourgeoning trails of economic, social, cultural and intellectual undertakings. To sustain these activities afloat varied vehicle types exploiting these axes create jams resultant of too many vehicles, bad roads, vehicle breakdown and on-street parking (accidents) affecting all age cohorts of urban users (Figure 3).

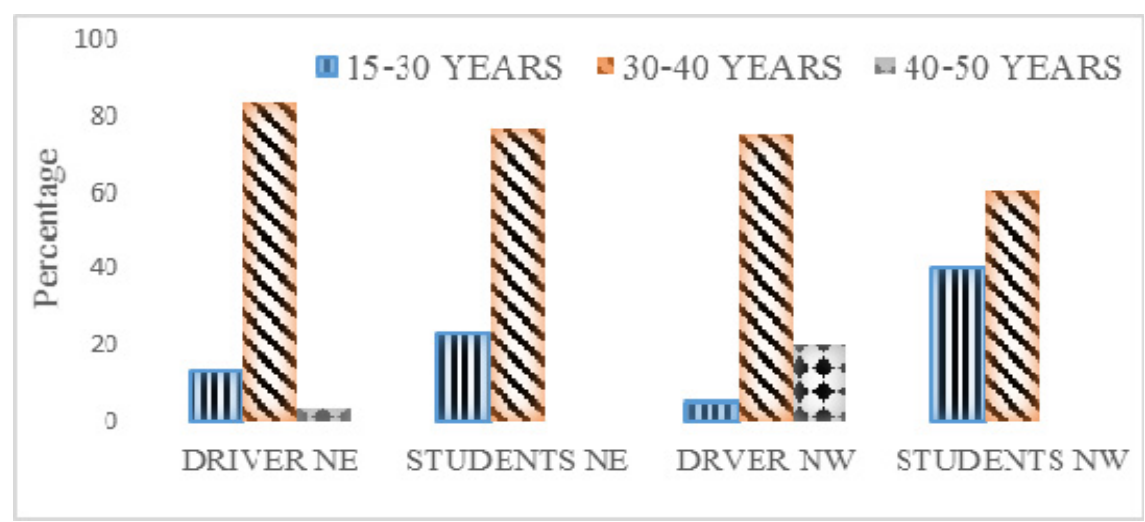

Figure 3. Age of road users on the Northern axis of Bamenda

There is a greater incidence towards the NE than NW because most of them attend the many higher institutions such as The University of Bamenda, BUST and National Polytechnic Bamenda while along the NW are only secondary schools such as C.C.C Mankon, Sacred Heart College Mankon and G.H.S Mankon (Figure 4). 


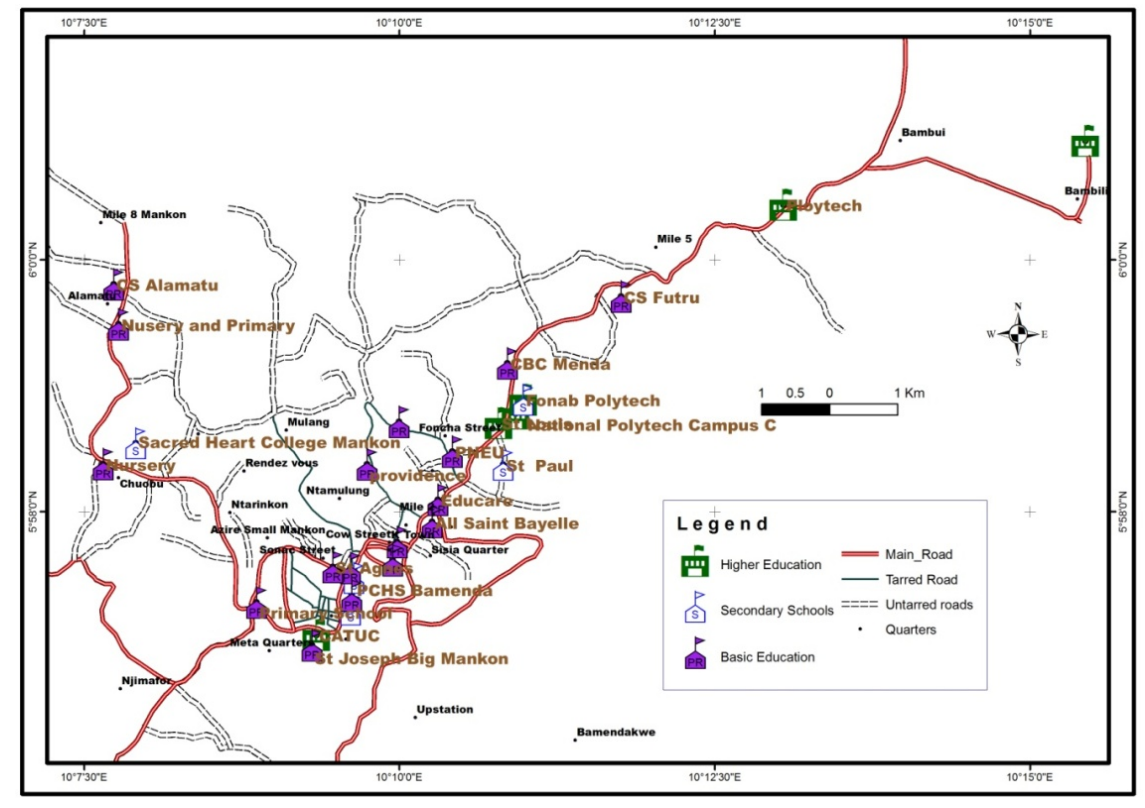

Figure 4. Institutionsof learning along the northern road axis of Bamenda

Source: May 2018.

Most students and staff for convenience, flexibility and accessibility are akin to using motor bikes to the extent that bikes are increasingly competing with vehicles for space on the narrow roads. Though such congestions portray an overall inability for all vehicular flow, the contribution of bikes in these jams appears significant though the road width is variable between Bamenda and Bambili (being $5.26 \mathrm{~m}$ from Bambui to Bambili, $10 \mathrm{~m}$ at AMOUR MEZAM EXPRESS, $8.53 \mathrm{~m}$ from Mile 4 to Bambui, 12 at Ngeng Junction and regularly $6 \mathrm{~m}$ from the Hospital Roundabout to Bafut. These variations tend to influence the vehicle users with more of those along the drivers of the NW road axis using personal vehicles so are more cautious as opposed to those along the NE road axis being mostly hired or "mercenaries" and so are less cautious of accidents and driving code rules that cause traffic jams (Figure 5).
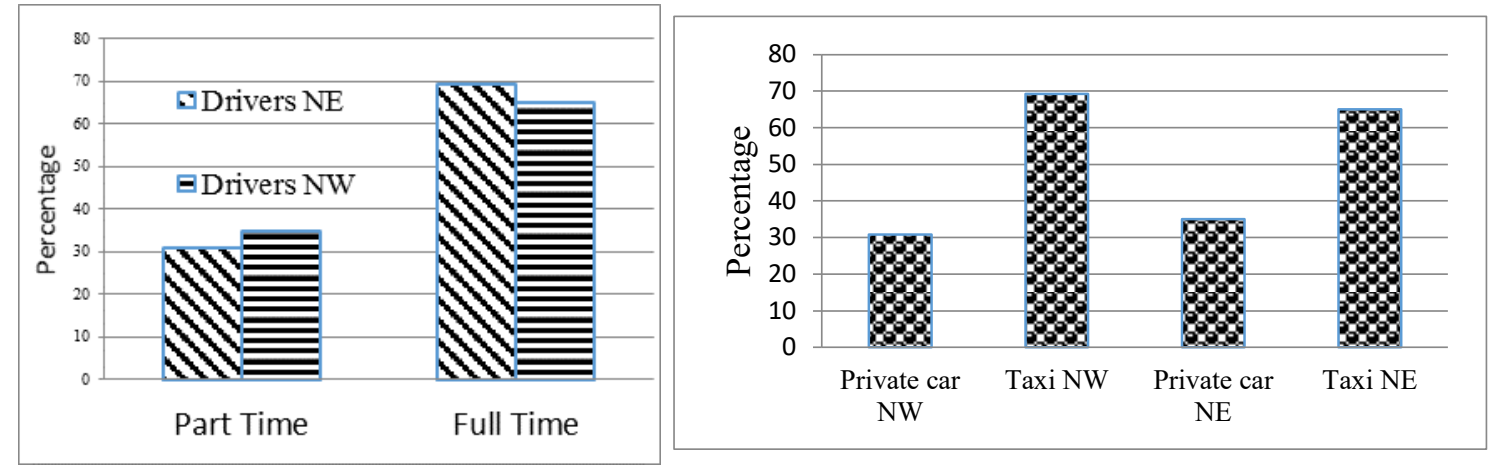

Figure 5. Category of road users along the peri-urban road axis

Source: Fieldwork, August 2018. 


\section{Macrothink}

International Journal of Global Sustainability

ISSN 1937-7924 2020, Vol. 4, No. 1

Some $69.2 \%$ of drivers in the NE road axis and $65 \%$ in the NW road axis drive on full time basis and consequently the greater the full time, the greater the congestion. These are workers and students who do not live within the vicinity of their schools and work places and are thus into the daily to and fro movements with either taxis and private cars or bikes since there no public mass transport system in Bamenda. Along both axes, there is clearly a dominance of taxis as a form of movement but with an increasing use of motor bikes by students at about 40 percent as mode of transport (Table 1).

Table 1. Vehicular flow pass sample points in Bamenda

\begin{tabular}{llllllllllll}
\hline & \multicolumn{1}{l}{ North West axis } & \multicolumn{1}{c}{ North East axis } \\
\cline { 2 - 13 } Month & \multicolumn{1}{l}{ All vehicular flow } & \multicolumn{4}{c}{ Bike proportion } & \multicolumn{2}{c}{ All vehicular flow } & \multicolumn{3}{c}{ Bike proportion } \\
& Mile 8 & Ntarinkon & Total & Number & $\%$ & Nkwen & Bambui & Total & Number & $\%$ \\
August & 4,335 & 12,382 & 16,717 & 6,833 & 40.87 & 15,172 & 6,053 & 21,225 & 7,418 & 34.94 \\
September & 4,103 & 11,504 & 15,607 & 6,171 & 39.53 & 18,302 & 3,102 & 21,404 & 9,636 & 45.01 \\
October & 4,498 & 13,063 & 17,561 & 7,160 & 40.77 & 12,454 & 6,062 & 18,516 & 7,113 & 38.41 \\
December & 4,300 & 12,579 & 16,879 & 6,659 & 39.45 & 18,331 & 6,915 & 25,246 & 7,411 & 29.35 \\
Sum & $\mathbf{1 7 , 2 3 6}$ & $\mathbf{4 9 , 5 2 8}$ & $\mathbf{6 6 , 7 6 4}$ & $\mathbf{2 6 , 8 2 3}$ & & $\mathbf{6 4 , 2 5 9}$ & $\mathbf{2 2 , 1 3 2}$ & $\mathbf{8 6 , 3 9 1}$ & $\mathbf{3 1 , 5 7 8}$ & \\
Mean & $\mathbf{4 3 0 9}$ & $\mathbf{1 2 , 3 8 2}$ & $\mathbf{1 6 , 6 9 1}$ & $\mathbf{6 7 0 5}$ & $\mathbf{4 0 . 1 5}$ & $\mathbf{1 6 , 0 6 4}$ & $\mathbf{5 , 5 3 3}$ & $\mathbf{2 1 , 5 9 8}$ & $\mathbf{7 , 8 9 5}$ & $\mathbf{3 6 . 9 2}$ \\
\hline
\end{tabular}

Source: Fieldwork, August 2018.

Rising urban poverty, joblessness issuant of the lack of industries and the political disarray of the Region since 2016, have had more and more young men into riding of motor bikes as source of livelihood. Riding on motor bikes syndrome rapidly gained grounds beyond students to other shades of road users because of its flexibility and greater accessibility. This is why in traffic jams, taxis, private cars and progressively motor bikes are involved and the bikes salvage the taxi-unserved zones of the urban unfortunates (Figure 6).

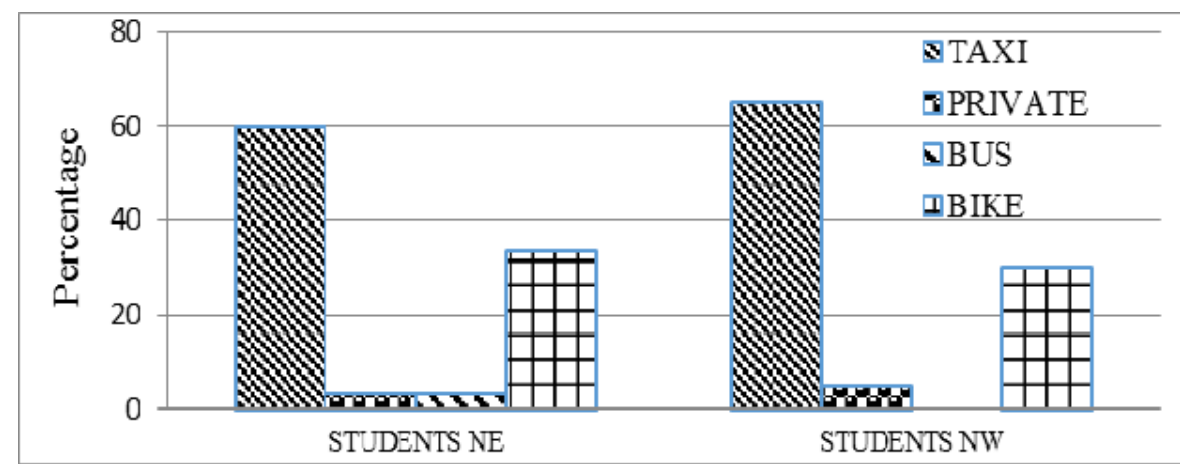

Figure 6. Student choice preference of transport modes in Bamenda

Source: Fieldwork, August 2018. 
Bikes are visibly in competition and also in complementarity to taxis in student choices. Private car is just $3.33 \%$ used by students, poverty imposed, and just no on or off-campus school bus shuttling services exist. Exposed to only what is available as means of movement, a traffic congestion acknowledgement by students and drivers was $60-80 \%$ respectively for most days of the week (Table 2).

Table 2. Road user acknowledgement of the number of congestion days in Bamenda

\begin{tabular}{lllllllll}
\hline Congestion days/week & \multicolumn{2}{l}{ Ntarikon - Bafut road axis } & \multicolumn{2}{l}{ Nkwen - Bambili road axis } \\
\cline { 2 - 9 } & Drivers & \multicolumn{3}{l}{ Students } & \multicolumn{2}{c}{ Drivers } & \multicolumn{2}{c}{ Students } \\
& Number & $\%$ & Number & $\%$ & Number & $\%$ & Number & $\%$ \\
2 & 0 & 0 & 2 & 6.7 & 0 & 0 & 0 & 0 \\
3 & 3 & 15 & 4 & 13.3 & 2 & 6.7 & 2 & 10 \\
4 & 6 & 30 & 7 & 23.3 & 7 & 23.3 & 4 & 20 \\
5 & 9 & 45 & 14 & 46.7 & 12 & 40 & 9 & 45 \\
6 & 2 & 10 & 3 & 10 & 8 & 26.7 & 4 & 20 \\
7 & 0 & 0 & 0 & 0 & 1 & 3.3 & 1 & 5 \\
\hline
\end{tabular}

Source: Fieldwork, August 2018.

Related implications of the congestion are lateness for lessons, psychological stress and tiredness. Workers to reported lateness to work, reduction in daily income, longer distances covered in route deviations, and garage expenditures due to malfunctioning of engines in rush hour queues. The only weekend day with traffic congestion from dawn to noon is on Saturdays when people go shopping amidst the multi-directional funeral convoys. Generally students noted congestion during the morning periods when they are rushing off to school and in the afternoon period when they are going back home from school (Table 3).

Table 3. Traffic congestion periodicity perception by road users in Bamenda

\begin{tabular}{|c|c|c|c|c|c|c|c|c|c|}
\hline \multirow{2}{*}{$\begin{array}{l}\text { Mean daily } \\
\text { congestion } \\
\text { period }\end{array}$} & \multirow[t]{2}{*}{$\begin{array}{l}\text { Time range } \\
\text { observed }\end{array}$} & \multicolumn{3}{|c|}{ Ntarikon - Bafut road axis } & & $\begin{array}{l}\text { Nkwen - } \\
\text { Drivers }\end{array}$ & mbili & $\begin{array}{r}\text { road ax } \\
\text { Students }\end{array}$ & \\
\hline & & Number & $\%$ & Number & $\%$ & Number & $\%$ & Number & $\%$ \\
\hline Morning & 6 am - 9 am & 11 & 55 & 12 & 65 & 18 & 60 & 19 & 63.3 \\
\hline Afternoon & $11 \mathrm{am}-2 \mathrm{pm}$ & 2 & 10 & 7 & 35 & 3 & 10 & 11 & 36.7 \\
\hline Evening & $5 \mathrm{pm}-7 \mathrm{pm}$ & 7 & 35 & - & - & 9 & 30 & - & - \\
\hline
\end{tabular}

Source: Fieldwork, August 2018.

Traffic congestion is higher in the morning period but not replicated in the afternoon and evening periods since in the mornings, various workers and students rush off to work and 
school between 7 and 9a.m (Table 4).

Table 4. Spatio-temporal variation in traffic flow in Bamenda

\begin{tabular}{|c|c|c|c|c|c|c|c|c|c|c|c|c|c|c|c|c|}
\hline \multirow{2}{*}{$\begin{array}{l}\text { Traffic } \\
\text { hours }\end{array}$} & \multicolumn{4}{|c|}{ Bambui } & \multicolumn{4}{|c|}{ Nkwen } & \multicolumn{4}{|c|}{ Ntarikon } & \multicolumn{4}{|c|}{ Mile 8} \\
\hline & Aug & Sept & Oct & Dec & Aug & Sept & Oct & Dec & Aug & Sept & Oct & Dec & Aug & Sept & Oct & Dec \\
\hline 6-7 am & 78 & 491 & 388 & 709 & 615 & 869 & 814 & 1492 & 777 & 491 & 1327 & 1251 & 777 & 360 & 564 & 288 \\
\hline 7-8 am & 801 & 623 & 576 & 977 & 1788 & 2459 & 1359 & 2544 & 1554 & 1318 & 1830 & 1819 & 1554 & 562 & 511 & 691 \\
\hline 8-9 am & 802 & 659 & 984 & 1095 & 1443 & 2559 & 1183 & 1915 & 1679 & 1798 & 1742 & 1600 & 1620 & 577 & 553 & 524 \\
\hline & 644 & 521 & 734 & 576 & & & & & & & & & & 350 & 461 & 529 \\
\hline $12-1 \mathrm{pm}$ & 649 & 499 & 631 & 657 & 1646 & 2001 & 1600 & 2263 & 1297 & 1251 & 1054 & 1154 & 1297 & 359 & 411 & 401 \\
\hline $1-2 \mathrm{pm}$ & 613 & 484 & 635 & 636 & 1968 & 1966 & 1462 & 1876 & 1360 & 1251 & 1134 & 1148 & 1630 & 481 & 491 & 331 \\
\hline $3-4 \mathrm{pm}$ & 624 & 599 & 667 & 599 & 1789 & 1837 & 1647 & 2151 & 1424 & 1424 & 1453 & 1395 & 1424 & 354 & 507 & 469 \\
\hline $4-5 \mathrm{pm}$ & 598 & 612 & 721 & 855 & 1897 & 2743 & 1388 & 1936 & 1490 & 1335 & 1634 & 1283 & 1410 & 356 & 416 & 477 \\
\hline $5-6 \mathrm{pm}$ & 622 & 614 & 726 & 811 & 2364 & 1890 & 1260 & 1635 & 1472 & 1391 & 1380 & 1126 & 1472 & 602 & 584 & 527 \\
\hline
\end{tabular}

Source: Fieldwork, August 2018.

The peak traffic jam hours were recorded as daily flow count. The same students and workers return at varied times so that some return in the afternoon (students) while others return in the evening (drivers). So there is a reduction in the number of people using the road as compared to the morning period. To appreciate how such jams are cushioned by motor bikes involvement, their numbers and percentage in the total traffic flow pass sample points was calculated (Table 5).

Table 5. Motor bikes as a proportion of traffic congestion vehicles in Bamenda

\begin{tabular}{|c|c|c|c|c|c|c|c|c|c|c|c|c|}
\hline \multirow{3}{*}{$\begin{array}{l}\text { Sample } \\
\text { period }\end{array}$} & \multicolumn{6}{|c|}{ North West axis } & \multicolumn{6}{|c|}{ North East axis } \\
\hline & Mile 8 & & & Ntarikon & & & Nkwen & & & Bambui & & \\
\hline & $\begin{array}{l}\text { Total } \\
\text { number }\end{array}$ & Bikes & $\%$ & $\begin{array}{l}\text { Total } \\
\text { number }\end{array}$ & Bikes & $\%$ & $\begin{array}{l}\text { Total } \\
\text { number }\end{array}$ & Bikes & $\%$ & $\begin{array}{l}\text { Total } \\
\text { number }\end{array}$ & Bikes & $\%$ \\
\hline August & 610 & 145 & 23.77 & 1554 & 689 & 44.33 & 1788 & 820 & 45.86 & 801 & 152 & 18.97 \\
\hline September & 562 & 128 & 22.77 & 1318 & 432 & 32.77 & 2459 & 1550 & 62.12 & 623 & 142 & 22.79 \\
\hline October & 511 & 136 & 26.61 & 1830 & 871 & 47.59 & 1359 & 675 & 49.66 & 576 & 125 & 21.70 \\
\hline December & 691 & 213 & 21.30 & 1819 & 874 & 48.04 & 2544 & 1535 & 60.33 & 977 & 197 & 19.95 \\
\hline
\end{tabular}

Source: Fieldwork, August 2018.

This causes some road users spend more time in traffic jams than others ranging from minutes to hours depending on the time, day, road axes and above all mode of transport used 


\section{Macrothink}

(Table 6).

Table 6. Amount of time lost in traffic congestion by road users in Bamenda

\begin{tabular}{|c|c|c|c|c|c|c|c|c|}
\hline \multirow{3}{*}{$\begin{array}{l}\text { Mean daily } \\
\text { congestion time loss } \\
\text { (minutes) }\end{array}$} & \multicolumn{4}{|c|}{ Ntarikon - Bafut road axis } & \multicolumn{4}{|c|}{ Nkwen - Bambili road axis } \\
\hline & \multicolumn{2}{|l|}{ Drivers } & \multicolumn{2}{|l|}{ Students } & \multicolumn{2}{|l|}{ Drivers } & \multicolumn{2}{|l|}{ Students } \\
\hline & Number & $\%$ & Number & $\%$ & Number & $\%$ & Number & $\%$ \\
\hline Less than 20 & 2 & 6.7 & 1 & 5 & 5 & 16.7 & 2 & 10 \\
\hline $21-30$ & 15 & 50 & 11 & 55 & 17 & 56.7 & 12 & 60 \\
\hline $31-60$ & 11 & 36.7 & 8 & 40 & 7 & 23.3 & 6 & 30 \\
\hline$>60$ & 2 & 6.7 & 0 & 0 & 1 & 3.3 & 0 & 0 \\
\hline
\end{tabular}

Source: Fieldwork, August 2018.

Road users lost more time in traffic congestion along the NE road axis than along the NW road axis due to a greater state of bad roads, has more educational institutes and offices than the NW road axis which calls for a greater number of users caught up in rush hours. Bad state of the road in the form of potholes impose themselves as uninvited speed breaks. Some 1,123 pot holes were counted along the northern road axes are concentrated between MOBIL Nkwen (Mile 1) to Mile 6 on the NE road axis and from Ntarikon Market to Mile 7 on the NW road axis (Figure 7).

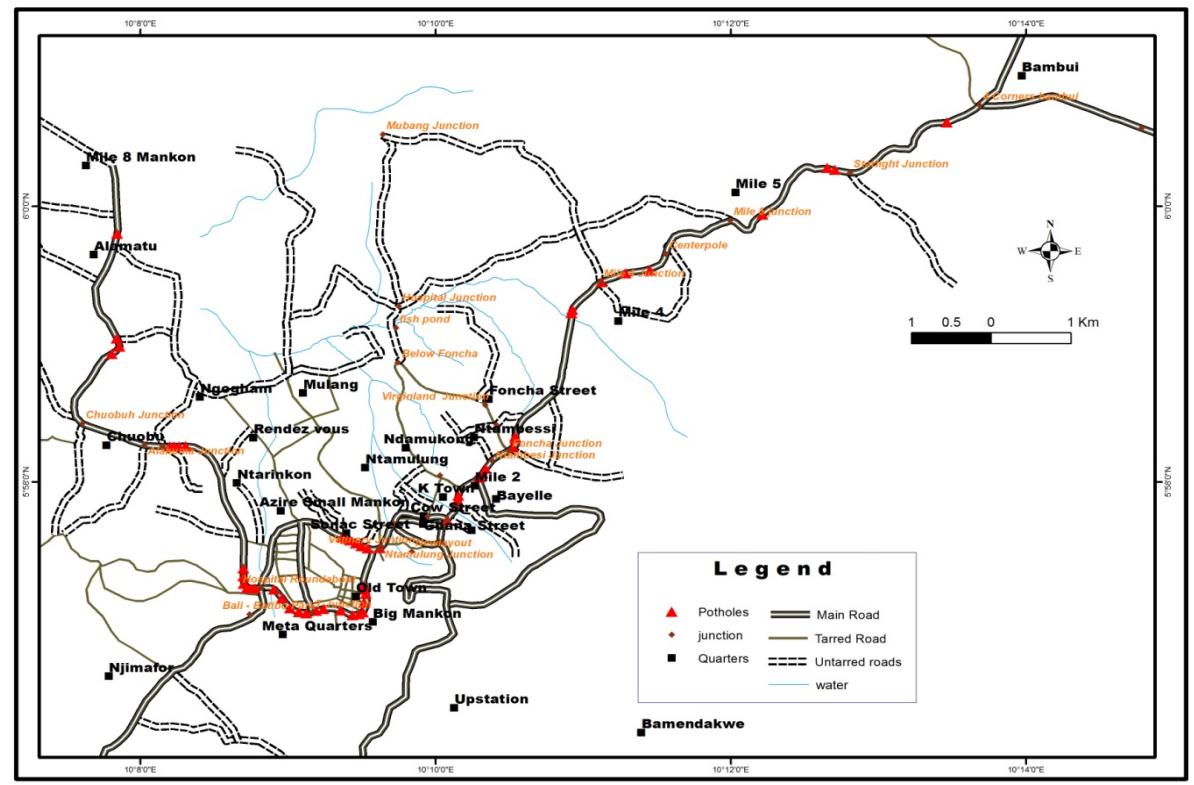

Figure 7. Pothole distribution on the northern road axis of Bamenda

Source: Fieldwork, July 2018 
Such a recurrence of pot holes lessens vehicular speed causing long queues given the small road lanes which makes road users to rather opt for motor bikes as a panacea.

\subsection{Biking Culture Palliative to Traffic Congestion Ramifications in Bamenda}

Inter and intra urban traffic congestion inflicts time and material losses in terms fuel and accidents on road users. This becomes a solution driven stratagem to salvage loses in daily income, time and money spent in garages. There is thus a near inability for drivers to accurately estimate travel time between nodes so the "just in case" time additions weigh on the urban productivity as trips that are shorter are covered for longer hours and this weighs on the standard of living as admitted variously by road users in different parts of the town.

Students and drivers on the Nkwen-Bambili axis felt greater loses fairly in proportion to the concentration of so many schools/colleges, economic activities and potholes with replications of tiredness in class, lateness to school and psychological stress, while drivers do fewer runs, fail to meet up with their daily income targets and spend in garages for repairs and varied maintenance (Figure 8).

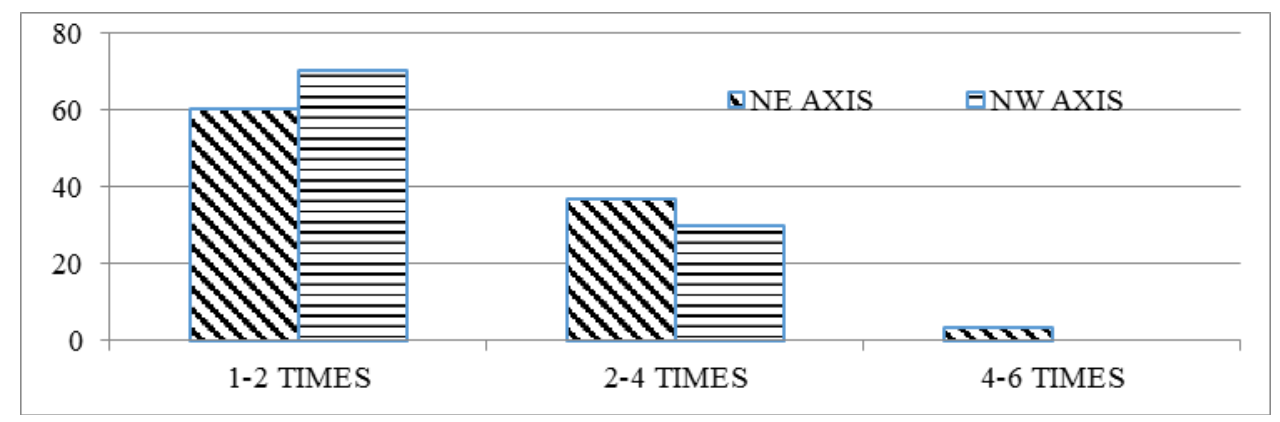

Figure 8. Weekly frequency of drivers to garages in Bamenda

There is this a high rate of frequenting garages which is at least once a week not just for engine servicing but necessary maintenance.

Traffic congestion has a big effect on workers of both private and public sectors since wasted time is money lost. There are late arrival for appointments and business meetings. The cumulative effect of the lateness sums up into $\mathrm{s}$ gruesome economic loss and a ruin to a staggering urban economy that is relatively at daggers drawn between political turmoil since 2016 and massive unemployment for dearth of veritable manufacturing enterprises. Tiredness in class, lateness to school and psychological stress cuts down on the overall staff and students' productivity in school and at examinations. To avoid these side effects road users at times engage in competing and hurrying transportation alternatives which often end up in accidents such that the victims may suffer from psycho-traumatic effects and even post-traumatic disorders let alone those who lose their lives and/or jobs (Table 7). 
Table 7. Accidents recorded along the NE and NW road axes of Bamenda

\begin{tabular}{|c|c|c|c|c|}
\hline Place & Date & Time & Vehicle type involved & Consequences \\
\hline $\begin{array}{l}\text { Mile } 9 \\
\text { (Bambili) }\end{array}$ & $23 / 02 / 2013$ & 6:00p.m. & Trucks vs. motorbike & $\begin{array}{l}-1 \text { dead (17years) } \\
-1 \text { seriously wounded } \\
\text { - damage on motorbike }\end{array}$ \\
\hline Mile 9 (Bambili) & $02 / 03 / 2013$ & 5:40p.m. & Private cars & $\begin{array}{l}-1 \text { wounded ( } 36 \text { years) } \\
\text { - damage on both vehicles }\end{array}$ \\
\hline Hospital Roundabout & $10 / 03 / 2013$ & 7:00a.m. & Trucks vs. taxi & $\begin{array}{l}-1 \text { dead ( } 25 \text { years }) \\
\text { - damage on taxi }\end{array}$ \\
\hline Mile 4 Junction Nkwen & $15 / 03 / 2014$ & 6:00 a.m. & Truck vs. private car & -1 wounded (40 years) \\
\hline Ntarikon Market & $15 / 04 / 2012$ & 9:35a.m. & Taxi vs. bus & $\begin{array}{l}-1 \text { dead (36years) } \\
\text { - damage on bus }\end{array}$ \\
\hline Mile 9-Bambili & $22 / 05 / 2012$ & 4:30p.m. & Taxi vs. truck & $\begin{array}{l}-4 \text { wounded }(27,34,37,30 \\
\text { years })\end{array}$ \\
\hline Bambili & $26 / 05 / 2014$ & 10:00 a.m. & Taxi on store & $\begin{array}{l}\text { - no human casualties } \\
\text { - material damage on store }\end{array}$ \\
\hline Four Corners Bambui & $31 / 05 / 2013$ & 9 a.m & Truck vs. private car & $\begin{array}{l}\text { - no human casualties } \\
\text { - damage on private car }\end{array}$ \\
\hline Mile 9 (Bambui) & 03/06/2012 & 7:45p.m. & Taxi vs. pedestrian & $\begin{array}{l}-1 \text { dead (55years) } \\
\text { - damage on taxi }\end{array}$ \\
\hline Mile 8 Mankon & 09/06/2013 & 3:30p.m. & Taxi vs. motorbike & $\begin{array}{l}\text {-1 dead (41 years) } \\
\text { - damage on motorbike }\end{array}$ \\
\hline $\begin{array}{l}\text { Mile } 7 \text { (Polytechnic } \\
\text { Bambui) }\end{array}$ & $17 / 06 / 2012$ & 5 p.m. & Taxi vs. motorbike & $\begin{array}{l}-4 \text { wounded }(62,26,50,52 \\
\text { years })\end{array}$ \\
\hline $\begin{array}{l}\text { Ntarikon } \quad \text { Council } \\
\text { Junction }\end{array}$ & 03/07/2014 & 8:00a.m. & Taxi vs. taxi & $\begin{array}{l}\text { - damage on both taxi and bike } \\
\text { - damage on both vehicles }\end{array}$ \\
\hline Bambui Polytechnic & $28 / 07 / 2012$ & 8:a.m & Taxi vs. pedestrian & $\begin{array}{l}-1 \text { dead and little damage on the } \\
\text { taxi }\end{array}$ \\
\hline $\begin{array}{l}\text { Mile } 3 \text { (Nkwen } \\
\text { GUINNESS Depot) }\end{array}$ & 06/08/2013 & 6:00 p.m. & Taxi vs. pedestrian & -1 injured (16 years) \\
\hline
\end{tabular}

Source: Regional Delegation of Transport for the North West, 2013-2014.

That traffic congestion has far reaching consequences beyond where it operates is indicative of the fact that motor biking as a partial solution which significantly contributes to peter out the bad side effects of congestion.

\section{Conclusion}

Traffic congestion has been found to be a recurrent plague of inter and intra-urban transport systems in Cameroonian towns and this does not seem to be unrelated to the state of the urban technical/dimensional road infrastructure and trait of vehicles plying on the axis. The 
need for economic gains and highest profitability has built in a spirit of time maximisation whose tragedy of the commons has become the resultant traffic jams and congestion. The consequences are multiform and victims are variedly inclusive of all road users. The situation and trend does not seem to announce any end time yet and so the transition of motorbikes at the start of the $21^{\text {st }}$ Century from personal to commercial use soon appeared to be a complementing panacea that strongly complemented urban transport where it was failing but has evolved into a mitigating palliative that is harnessing instant and short term quagmires of neglected urban mass transit systems. Necessity has unconsciously let emerge a hitherto transport system form personal to commercial and its splendour in Cameroonian city fluxes does not hide any future of it being a mass transit system only begging to be formalised and organised in its space and mundus operandi of urban transport governance.

\section{Acknowledgement}

The research received support from the Internal Research Allowance for staff of the University of Bamenda, Cameroon.

\section{References}

Immers, L. H., \& Logghe, S. (2002). Traffic Flow Theory. Katholieke University, Belgium.

Lam, S. H., \& Toan, T. D. (2006). Land transport Policy and Public transport in Singapore. Journal of Transportation, 33(2). https://doi.org/10.1007/s11116-005-3049-z

MacLachlan, I. (2015). Quantitative Models for Geographical Analysis: Additional Required Reading for Geography, Lectures (Spring 2015), University of Lethbridge, Alberta.

Memmott, T., \& Young, P. (2008). Seasonal Variation in Traffic Congestion: A Study of Three U.S. Cities. U.S. Department of Transportation Research and Innovative Technology Administration, Technical report No. 005.

Rakha, H., \& Van Aede, M. (1995). Statistical Analysis of Day-to-Day Varations in Real-Time Traffic Flow Data. Transportation Research Record 1510 (pp. 26-34). TRB, National Research Council, Washington DC.

Rosen, A. (2013, July 8). What really causes traffic congestion?

Rumani, S. P. (2014). Traffic Congestion in Delhi: Causes, Outcomes and Solutions.

Shbaklo, S., Koppelman, F., \& Bhat, C. (1992) Static Prediction Models of Flow and Occupancy. Report TRF-TT-05. ADVANCE, Transportation Center, North Western University, Evanston, Belgium.

\section{Copyright Disclaimer}

Copyright for this article is retained by the author(s), with first publication rights granted to the journal.

This is an open-access article distributed under the terms and conditions of the Creative Commons Attribution license (http://creativecommons.org/licenses/by/3.0/). 